Журнал«Герспективитаінноваціїнаукиљ

(Серія«Герагогіка», Серія«Гцихологія», Серія«Медицинв»

№2(7) 2022

УДК 159.9-051]:376:373.5

https://doi.org/10.52058/2786-4952-2022-2(7)-870-879

Калиновська Ірина Сергіївна кандидат педагогічних наук, доцент кафедри спеціальної та інклюзивної освіти, Уманський державний педагогічний університет імені Павла Тичини, вул. Садова, 2, м. Умань, 20301, тел.: (04744) 3-45-82, https://orcid.org/0000-0001-8805-4641

\title{
ФУНКЩІЇ ПРОФЕСІЙНОЇ ДІЯЛЬНОСТІ ПРАКТИЧНИХ ПСИХОЛОГІВ В УМОВАХ ІНКЛЮЗИВНОЇ ЗАГАЛЬНОЇ СЕРЕДНЬОЇ ОСВІТИ
}

Анотація. У статті з'ясовано сутність професійної діяльності практичних психологів в умовах інклюзивного навчання учнів закладів загальної середньої освіти як вмотивованого комплексу напрямів і функцій обов'язкового учасника команди психолого-педагогічного супроводу учнів 3 особливими освітніми потребами, якісне виконання яких забезпечує успіх вирішення завдань психолого-педагогічної та корекційно-розвивальної роботи.

Під час розгляду проблеми окреслено функції практичних психологів закладів загальної середньої освіти (психологічне забезпечення процесу освіти; психологічна діагностика та супровід психічного, розумового, соціального та фізичного розвитку здобувачів середньої освіти; психологічний супровід адаптації здобувачів середньої освіти до цього процесу; консультативна допомога (щодо навчання, виховання, особистісного та професійного розвитку) та реалізація розвивальних, просвітницьких, корекційних та професійних програм з урахуванням особливостей (індивідуальних, гендерних, вікових тощо) усіх учасників процесу загальної середньої освіти; робота 3 постраждалими від насильства учнями).

Огляд сукупності практичних завдань діяльності психолога в умовах інклюзивної освіти, дав змогу схарактеризувати іï поліфункціональність та виокремити функції професійної діяльності майбутніх практичних психологів: діагностування особливих освітніх потреб дітей; створення інклюзивного освітнього середовища; надання психологічних та корекційно-розвиткових послуг; навчання учнів з особливими освітніми/типовими потребами засобами корекції психофізичного розвитку; консультування учасників освітнього процесу в умовах інклюзивного навчання; психологічний супровід школярів 3 особливими/типовими освітніми потребами в умовах обов'язкової взаємодії 3 їхніми батьками; просвітницько-співробітницька діяльність щодо психологічного супроводу інклюзивного навчання.

Оцінюючи зусилля науковців у висвітлені даної проблематики, вважаємо, що перспективами подальших наукових розвідок $є$ формування професійної готовності майбутніх практичних психологів до роботи в умовах інклюзивного навчання учнів закладів загальної середньої освіти. 
Ключові слова: Інклюзивне навчання, професійна діяльність практичних психологів, професійні функції практичних психологів в умовах інклюзивної освіти.

Kalynovska Iryna Sergeevna Candidate of Pedagogical Sciences, Senior Lecturer Department of Special and Inclusive Education, Pavlo Tychyna Uman State Pedagogical University, Sadova St., 2, Uman, 20301, tel.: (04744) 3-45-82, https://orcid.org/0000-0001-8805-4641

\section{FUNCTIONS OF PROFESSIONAL ACTIVITY OF PRACTICAL PSYCHOLOGISTS IN CONDITIONS OF INCLUSIVE GENERAL SECONDARY EDUCATION}

Abstract. The article clarifies the essence of professional activity of practical psychologists in the conditions of inclusive education of students of general secondary education institutions as a motivated set of directions and functions of obligatory member of the team of psychological and pedagogical support of students with special educational needs, high-quality implementation of which ensures the success of solving problems of psychological and pedagogical and correctional and developmental work.

During the consideration of the problem the functions of practical psychologists of general secondary education institutions are outlined (psychological support of the educational process; psychological diagnostics and support of mental, intellectual, social and physical development of secondary school students; psychological support of secondary school students' adaptation to this process; education, personal and professional development) and implementation of developmental, educational, correctional and professional programs taking into account the characteristics (individual, gender, age, etc.) of all participants in the process of general secondary education; work with victims of violence).

Review of the set of practical tasks of a psychologist in an inclusive education, allowed to characterize its multifunctionality and highlight the functions of professional activities of future practical psychologists: diagnosing special educational needs of children; creating an inclusive educational environment; provision of psychological and correctional and developmental services; teaching students with special educational / typical needs the means of correction of psychophysical development; advising participants of the educational process in the conditions of inclusive education; psychological support of students with special / typical educational needs in the conditions of obligatory interaction with their parents; educational and collaborative activities on psychological support of inclusive education.

Assessing the efforts of scientists to cover this issue, we believe that the prospects for further research are the formation of professional readiness of future practical psychologists to work in inclusive education of students of general secondary education. 
Keywords: Inclusive education, professional activity of practical psychologists, professional functions of practical psychologists in the conditions of inclusive education.

Постановка проблеми. Концепція соціальної та освітньої рівності усіх людей незалежно від стану здоров'я, наявності фізичного чи інтелектуального порушення, рівнів розвитку, національної чи етнічної приналежності, віросповідання та ін. - $€$ одним із головних завдань розвитку інклюзії як відгуку на широкий спектр освітніх потреб в шкільному середовищі та поза його межами. Цей ціннісний імператив відповідає пріоритетам сучасної державної політики: Закони України «Про освіту» (2017), «Про повну загальну середню освіту» (2020), постанова Кабінету Міністрів України «Про затвердження Порядку організації інклюзивного навчання у загальноосвітніх навчальних закладах» (2011, 2020), Концепція «Нова українська школа» (2016), «Про затвердження Примірного положення про команду психолого-педагогічного супроводу дитини 3 особливими освітніми потребами в закладі загальної середньої та дошкільної освіти» (2018) та інші нормативні акти. В документах акцентовано увагу на комплексній системі різнобічної, динамічної, корекційної і розвивальної допомоги усім дітям, відповідно до вікових та індивідуальних потреб. Зокрема, йдеться про надання системного психолого-педагогічного супроводу кожній дитині та методичної допомоги іiї родині. Тому діяльність практичних психологів в інклюзивному освітньому середовищі охоплює розширений комплекс професійних функцій.

Аналіз останніх досліджень i публікацій. Питанню професійної діяльності практичних психологів в умовах інклюзивного освітнього середовища присвячено праці сучасних вітчизняних науковців (А. Колупаєва, Л. Гречко, В. Засенко, З. Ленів, М. Матвеєва, Т. Сак, В. Синьов, М. Швед та ін.). Варто сказати, що сукупність окреслених наукових напрацювань становить незначну частку комплексної проблеми професійної діяльності практичних психологів з учнями загальноосвітніх навчальних закладів, які проваджують інклюзивне навчання. Основний масив невирішених завдань стосується професійних функцій практичного психолога та їх якісного виконання.

Мета статті - проаналізувати та конкретизувати функції професійної діяльності практичних психологів в умовах інклюзивного навчання учнів закладів загальної середньої освіти.

Виклад основного матеріалу. У концепції «Нова українська школа» (2016) [4] вказано головні правила реалізації інклюзивного навчання у 33СО України: запровадження для учнів з ООП індивідуальних програм розвитку, у тому числі - корекційно-реабілітаційні заходи та психолого-педагогічний супровід [4, с. 20]; запровадження принципу «гроші ходять за дитиною» для підтримки учнів з ООП, передусім, пристосування приміщень, у яких вони будуть навчатися [4, с. 29]. Знову ж, наскрізно зазначено, що іiі реалізацію мають здійснювати лише кваліфіковані фахівці, спеціально підготовані чи 
перепідготовлені у закладах вищої освіти. Водночас, не прописано чітких обов'язків практичних психологів в умовах інклюзивного навчання у закладах загальної середньої освіти.

Сутність посади практичного психолога як штатного працівника закладу загальної середньої освіти та обов'язкового учасника команди психологопедагогічного супроводу учнів 3 ООП, спільно 3 директором/заступником директора 3 навчально-виховної роботи 33СО, вчителем початкової школи / класним керівником, учителями, асистентом учителя, соціальним педагогом, учителем-дефектологом, учителем-реабілітологом (за потреби), батьками/чинними представниками учня 3 ООП, окреслено «Примірним положенням про команду психолого-педагогічного супроводу дитини 3 особливими освітніми потребами в закладі загальної середньої та дошкільної освіти» [7, с. 2-7]. Посадові обов'язки, функції як і загалом професійна діяльність практичних психологів регламентуються також «Положенням про психологічну службу у системі освіти України» (2018) [6, с. 3-7], у якому визначено такі засади діяльності практичних психологів у закладах загальної середньої освіти:

1. Посада практичного психолога у закладах загальної середньої освіти, разом із соціальним педагогом, належить до складу психологічної служби.

2. Практичні психологи здійснюють психологічне забезпечення процесу загальної середньої освіти, в усіх питаннях діяльності підпорядковуючись директору закладу освіти.

3. Чинні функції практичних психологів закладів загальної середньої освіти: психологічне забезпечення процесу освіти; психологічна діагностика та супровід психічного, розумового, соціального та фізичного розвитку здобувачів середньої освіти; психологічний супровід адаптації здобувачів середньої освіти до цього процесу; консультативна допомога (щодо навчання, виховання, особистісного та професійного розвитку) та реалізація розвивальних, просвітницьких, корекційних та професійних програм 3 урахуванням особливостей (індивідуальних, гендерних, вікових тощо) усіх учасників процесу загальної середньої освіти; робота 3 постраждалими від насильства учнями.

4. Практичні психологи закладу загальної середньої освіти беруть участь в усіх видах його діяльності та розробці й впровадженні програм, планів, рекомендацій тощо для здобувачів середньої освіти.

5. Практичні психологи у закладах загальної середньої освіти мають спонукати в учнів формування: життєвої та соціально-комунікативної компетентності у здобувачів середньої освіти, їхнього професійного самовизначення та самореалізації; основам безпечної поведінки у житті; психологічної культури та небайдужого ставлення до постраждалих. Він має запобігати професійному вигоранню працівників закладів загальної середньої освіти та будь-яким видам і формам насильства, конфліктів серед здобувачів загальної середньої освіти. 
6. Практичні психологи мають володіти спеціальними ключовими знаннями та уміннями.

Аналіз вказаного вище положення вказує на те, що бракує конкретних указівок діяльності практичних психологів в умовах інклюзивного навчання учнів закладів загальної середньої освіти, оскільки такі знання та уміння регламентуються іншим чинним положенням. Звертаємо увагу на те, що зміст професійної діяльності практичних психологів у закладах загальної середньої освіти не передбачає роботу 3 обдарованими учнями, не зважаючи на значущість таких аспектів: обдаровані школярі належать до категорії учнів 3 ООП; у чинних нормативних документах, на яких грунтується діяльність закладів загальної середньої освіти (Закони України «Про освіту», «Про загальну середню освіту»; Концепції «Нова українська школа» та ін.) чітко вказана необхідність та обов’язковість роботи з обдарованими учнями.

«Примірним положенням...» визначено, відповідно до завдань діяльності команди супроводу, основні функції практичних психологів, які вони мають виконувати в рамках основного робочого часу (без додаткових оплат). Таким чином, практичні психологи для дитини/учня з ООП мають:

1. Вивчати та моніторити їі/його психічний розвиток.

2. Психологічно супроводжувати в умовах такого навчання.

3. Здійснювати корекційно-розвиткові послуги у рамках розробленої та затвердженої індивідуальної програми розвитку.

4. Надавати рекомендації, консультації та методичну допомогу педагогічним працівникам, які працюють з дитиною з ООП.

5. Консультувати батьків учнів.

6. Провадити просвітницько-психологічну діяльність 3 метою формування у суб'єктів інклюзивного освітнього процесу психологічної готовності до взаємодії із учнями з особливими освітніми потребами [8].

Зауважимо, що вказаним Примірним положенням об’єднано два напрями діяльності - навчання та консультування - до однієї функції: «надавати рекомендації, консультації та методичну допомогу педагогічним працівникам, які працюють 3 дитиною з ООП». Тому загалом напрямів діяльності практичних психологів - сім, а функцій - шість (вивчення та могніторинг психічного розвитку учнів 3 ООП; психологічний супровід учнів 3 ООП; надання корекційно-розвиткових послуг учням 3 ООП згідно 3 індивідуальною програмою їхнього розвитку; надання рекомендацій, консультацій та методичної допомоги педагогічним працівникам, які працюють 3 учнями 3 ООП; консультування батьків учнів з ООП; просвітницька діяльність щодо формування психологічної готовності загалом суб'єктів освітнього процесу до взаємодії з учнями з ООП) [8].

Отже, одне із завдань практичних психологів - допомогти учням з ООП продуктивно розвиватися, зводячи до мінімуму ймовірні негативні наслідки їхньої поведінки у процесі навчання у $33 \mathrm{CO}$ (надання корекційно-розвиткових послуг згідно із відповідним Положенням [8]). 
У наукових джерелах (Т. Грандін [10], А. Колупаєва [3]) визначено такі особливості поведінки учнів з ООП, на які мають звернути увагу практичні психологи у 3ЗСО (діагностувати, моніторити, коректувати тощо):

-шкільна дезадаптація з причини низької стресостійкості;

-індивідуально-типологічна поведінка у відповідності до психофізичного розладу учня (наприклад, учнів 3 розладами аутистичного спектру: агресія, обмежені інтереси, особливості гри, проблеми соціального та вербального характеру, неадекватні емоції, стереотипи, спеціальні рухи та хода, надмірне почуття самозбереження тощо);

-стан тривожності, спричинений, найчастіше розлукою 3 матір'ю та адаптацією до дитсадка, школи тощо;

-нервові зриви, неадекватна самооцінка, незадоволеність собою та іншими, конфліктність, психосоматичні проблеми як наслідки вказаного вище тощо.

Дослідники одностайні у тому, що проблеми поведінки в учнів 3 ООП загострюються саме у період навчання у закладах освіти. Одним із найефективніших методів роботи щодо усунення таких проблем дослідники називають методи корекції. Найефективнішими методи корекції $є$ у взаємодії практичних психологів та вчителів. Причому, найвідповідальніша роль належить практичним психологам, компетентність яких виявляється у виборі адекватного методу корекції поведінкових порушень учнів з ООП у ЗЗСО. Така корекція - комплексний, системний та систематичний процес за участю усіх суб'єктів закладу інклюзивного навчання. Тому надалі у нашому дослідження нам необхідно буде визначити у процесі виробничої практики професійної підготовки майбутніх психологів методику здійснення аналізу застосування корекційних методів інклюзивного навчання 3 точки зору їхньої спільної реалізації педагогами та практичними психологами.

3'ясовуючи психологічні причини конфліктних ситуацій між учасниками інклюзивного навчання (переважно, між педагогами та учнями 3 ООП), практичні психологи зобов'язані також проаналізувати психологічні аспекти методики навчання педагогом такого учня. Це - виконання психологами професійної функції у вигляді надання консультацій, рекомендацій, методичної допомоги педагогічним працівникам та іншим учасникам освітнього процесу, які працюють з учнями з особливими освітніми потребами.

Щодо виконання практичними психологами професійної функції «консультування батьків», то, переважно, у дослідженнях (Н. Байбекова, I. Войціх, Г. Гончаровська, О. Затворнюк, С. Наход, Л. Смалиус, Л. Сухоставська та ін.) розуміють інклюзивну освіту як систему з ії класичною проблемою: особливості інклюзивної освіти за умови «неоднорідності» батьківської спільноти, тобто розуміння того, що, переважно, батьки учнів 3 типовими освітніми потребами не сприймають, а, почасти, протестують проти інклюзивного навчання; натомість, батьки дитини з ООП, переважно, схильні до інклюзивної освіти. 
Журнал«Герспективитаінновації наукиљ

(Серія«Гедагогіка», Серія«Гцихологія», Серія«Медицинв»

№2(7) 2022

Дослідниками (К. Гудзь, С. Єфімова, С. Добриніна, I. Калініченко, А. Колупаєва, I. Кузава та ін.) констатовано, що ефективність прийняття батьками учнів інклюзивної освіти визначається адекватним вибором форм i технологій, обраних педагогами та практичними психологами для поставлених завдань.

Дослідники (С. Альохіна, В. Бобрицька, В. Бойко, Т. Гладун, А. Колупаєва, В. Тарасун, В. Синьов та ін.) найхарактернішою рисою інклюзивного навчання у закладах освіти визначають його полісуб'єктність, зважаючи на кінцеву його мету - соціалізацію учнів з ООП у соціумі. Водночас кожен суб'єкт (сама дитина з ООП, іiі батьки, вчителі, адміністрація та ін.) почасти має свою, відмінну від інших, точку зору на становлення дитини з ООП. Саме про узгодження таких позицій та їх представлення в єдиному організаційнопсихологічному вимірі і $є$ завданням ефективного інклюзивного навчання.

Попри те, що батьки відіграють ключову роль у розвитку та становленні будь-якої дитини, вкрай вирішальну, далеко не завжди позитивну, роль вони відіграють у ситуації із дитиною з ООП. Як констатують результати нашого опитування та спостереження, батьки занадто часто, особливо у ситуації, коли дитина з ООП з причин особливості хвороби не здатна висловити, або відстояти свою точку зору, приймають авторитарне рішення за долю дитини, усупереч іiі інтересів. За таких умов практичні психологи мають виконувати роль медіаторів, упереджуючи аналогічну ситуацію на основі попередньо складеної характеристики батьків учнів: передбачуючи та запобігаючи ймовірному конфлікту від батьків, здатних створити критичну ситуацію у спілкуванні. Якщо ситуація конфлікту інтересів вже виникла, практичні психологи покликані щонайшвидше спонукати усіх іï учасників знайти компромісне рішення в інтересах учня з особливими/типовими освітніми потребами та інших учасників процесу навчання (однокласників учня, вчителів та ін.). 3 цією метою практичні психологи мають систематично працювати у сфері самовдосконалення, відшуковуючи інноваційні форми співпраці із суб'єктами інклюзивного навчання.

Значуща роль у контексті інклюзивного навчання покладена на психологопедагогічний (соціально-психологічний) супровід такого навчання, який, згідно із тарифними ставками, залежно від регіональних можливостей, виконують або вчителі, або практичні психологи. Психолого-педагогічний супровід, На думку I. Калініченко, О. Чопік, здійснюється за такими конкретними напрямами: своєчасне виявлення та фіксація даних учнів 3 ООП - їхня соціальна паспортизація (I. Калініченко) [2, с. 10]; психологічна та моральна підготовка учнів з ООП до включення у колектив учнів з типовими освітніми потребами; створення для учнів з ООП соціально-комунікативної ситуації успіху шляхом застосування методів інтерактивного навчання («Коло ідей», «Акваріум», «Мікрофон», «Незакінчене речення», «Прес», «Обери позицію», мозковий штурм, аналіз моральної ситуації, рольова гра, «ситуації успіху» тощо) та спеціальних виховних заходів (етичні бесіди, екскурсії, система морально- 
етичних занять); спеціальна підготовка та перепідготовка педагогічного колективу інклюзивного закладу загальної середньої освіти («тематичні педради, методоб'єднання, семінари-практикуми, консультації з практичним психологом, соціальним і корекційним педагогами, дискусії») (О. Чопік) [9, с. 11] тощо.

Враховуючи результати наукових досліджень (С. Альохіна [1], В. Бобрицька, В. Бойко, Т. Гладун, А. Колупаєва, В. Тарасун, В. Синьов та ін.) та аналіз нормативно-правової бази [5; 6; 7], що регламентує професійну діяльність практичних психологів в умовах інклюзивного навчання учнів закладів загальної середньої освіти, нам вдалося узагальнити напрями і функції професійної діяльності практичних психологів у 33СО:

1. Психологічний супровід учасників освітнього процесу у З3СО узагальнене окреслення сутності професійної діяльності практичних психологів у закладах загальної середньої освіти. Такий супровід конкретизується напрямами, функціями діяльності, посадовими обов'язками та відповідними знаннями, уміннями.

2. Продуктивність професійної діяльності практичних психологів в умовах інклюзивного навчання учнів закладів загальної середньої освіти, насамперед, здійснюваного ними психологічного супроводу учнів 3 особливими/типовими освітніми потребами, залежить від їхнього уміння застосовувати командний підхід - об'єднувати учасників вказаного навчання у 33СО 3 метою активної співпраці та позитивного вирішення ситуацій психологічного характеру.

3. Учасниками освітнього процесу у інклюзивних закладах загальної середньої освіти є: учні з особливими/типовими освітніми потребами, вчителі, батьки учнів, адміністрація закладу.

4. Інклюзивне навчання передбачає рівні права його учасників, тому суміжно вживаємо поняття «учні 3 ТОП та 3 ООП» або «учні 3 особливими/типовими освітніми потребами», щоб, по-перше, акцентувати на інклюзивності - спільному навчанні учнів обох категорій в умовах закладу загальної середньої освіти, а, по-друге, наголосити на тому, що учні з ООП потребують особливої уваги 3 причини ускладненого психофізіологічного стану.

5. Оскільки обдаровані діти належать до категорії дітей з ООП, проте їхньому навчанні в умовах інклюзії на нормативно-науковому рівні недостатньо приділено уваги, нами у напрямах діяльності практичних психологів акцентовано на цьому аспекті професійної психологічної діяльності.

Зауважимо, що напрям діяльності: «зв’язок із громадськістю» [6, с. 8], переформульований нами у «зв'язок 3 учасниками інклюзивної освіти», оскільки у Положенні йдеться про командну роботу - спільну із соціальним педагогом, а ми аналізуємо лише складник цього напряму - роботу практичних психологів.

Отже, сутність професійної діяльності майбутніх практичних психологів в умовах інклюзивного навчання учнів закладів загальної середньої освіти як 
вмотивованого комплексу напрямів і функцій обов'язкового учасника команди психолого-педагогічного супроводу учнів з особливими освітніми потребами, якісне виконання яких забезпечує успіх вирішення завдань психологопедагогічної та корекційно-розвивальної роботи за такими напрямами: діагностика, профілактика, корекція, навчання, консультування, зв’язок 3 учасниками інклюзивної освіти, просвіта.

Висновки. У процесі розгляду проблеми професійної діяльності практичних психологів в умовах інклюзивної загальної середньої освіти визначено основні напрями i функції професійної діяльності майбутніх практичних психологів: діагностування особливих освітніх потреб дітей; створення інклюзивного освітнього середовища; надання психологічних та корекційно-розвиткових послуг; навчання учнів 3 особливими освітніми/типовими потребами засобами корекції психофізичного розвитку; консультування учасників освітнього процесу в умовах інклюзивного навчання; психологічний супровід школярів 3 особливими/типовими освітніми потребами в умовах обов'язкової взаємодії 3 їхніми батьками; просвітницькоспівробітницька діяльність щодо психологічного супроводу інклюзивного навчання. Перспективами подальших наших наукових розвідок $є$ формування професійної готовності майбутніх практичних психологів до роботи в умовах інклюзивного навчання учнів закладів загальної середньої освіти.

\section{Jimepamypa:}

1. Альохіна С. Інклюзивна освіта в Украйні: здобутки, проблеми та перспективи: резюме аналітичного звіту за результатами комплексного. URL: http://www.twirpx.com/fle/974948 (дата звернення: 18.01.2021).

2. Калініченко I. О. Виховання підлітків з особливими освітніми потребами в умовах інклюзивного освітнього середовища: автореф. дис. ... канд. пед. наук: 13.00.07. Луганськ, 2014. $23 \mathrm{c}$.

3. Колупаєва А. А. Інклюзивна освіта якісна освіта для всіх. Інклюзивна освіта: реалії та перспективи: монографія. Київ: Саміт-Книга, 2009. С. 5-31.

4. Нова українська школа: концепція. URL: http://mon.gov.ua/ua/tag/nova-ukrainskashkola (дата звернення: 24.01.2022 р.).

5. Положення про інклюзивно-ресурсний центр: Постанова Кабінету міністрів України від 12 липня 2017 р. № 545, https://zakon.rada.gov.ua/laws/show/545-2017$\% \mathrm{D0 \% BF \# Text} \mathrm{(дата} \mathrm{звернення:} \mathrm{24.01.2022).}$

6. Про затвердження Положення про психологічну службу у системі освіти України: Наказ Міністерства освіти i науки України від 22.05.2018 p. № 509. URL: https://zakon.rada.gov.ua/laws/show/z0885-18 (дата звернення: 24.01.2022).

7. Про затвердження Примірного положення про команду психолого-педагогічного супроводу дитини з особливими освітніми потребами в закладі загальної середньої та дошкільної освіти: Наказ Міністерства освіти і науки України від 08.06.2018 p. № 609. https://mon.gov.ua/ua/npa/pro-zatverdzhennya-primirnogo-polozhennya-pro-komandu-psihologopedagogichnogo-suprovodu-ditini-z-osoblivimi-osvitnimi-potrebami-v-zakladi-zagalnoyi-serednoyita-doshkilnoyi-osviti (дата звернення: 24.01.2022).

8. Стандарт вищої освіти за спеціальністю «Психологія» для першого (бакалаврського) рівня вищої освіти (затверджений і введений в дію наказом Міністерства освіти і науки № 565 від 24 квітня 2019 р.). URL: http://osvita.ua/vnz/standard/64445/ (дата звернення: 24.01. 2022). 
9. Чопік О. В. Формування взаємин дітей 3 вадам опорно-рухового апарату із здоровими ровесниками в умовах інклюзивного навчання: автореф. дис. ... канд. пед. наук: 13.00.03. Київ, 2014. 21 с.

10. Grandin T. Teaching Tips for Children and Adults with Autism. Indiana University Bloomington. 2002. URL: https://www.iidc.indiana.edu/pages/Teaching-Tips-for-Children-andAdults-with-Autism (дата звернення: 24.01.2022).

\section{References:}

1. Al'ohina, S. Inkljuzivna osvita v Ukrajni: zdobutki, problemi ta perspektivi: rezjume analitichnogo zvitu za rezul'tatami kompleksnogo [Inclusive education in Ukraine: achievements, problems and prospects: a summary of the analytical report on the results of the complex]. www.twirpx.com Retrived from http://www.twirpx.com/fle/974948 [in Ukrainian].

2. Kalinichenko, I. O. (2014). Vihovannja pidlitkiv z osoblivimi osvitnimi potrebami v umovah inkljuzivnogo osvitn'ogo seredovishha [Education of adolescents with special educational needs in an inclusive educational environment]. Extended abstract of candidate's thesis. Lugans'k [in Ukrainian].

3. Kolupa€va, A. A. (2009). Inkljuzivna osvita jakisna osvita dlja vsih. Inkljuzivna osvita: realii ta perspektivi [Inclusive education quality education for all. Inclusive education: realities and prospects]. Kiïv: Samit-Kniga [in Ukrainian].

4. Nova ukraïns'ka shkola: koncepcija [New Ukrainian school: concept]. mon.gov.ua Retrived from http://mon.gov.ua/ua/tag/nova-ukrainska-shkola [in Ukrainian].

5. Postanova Kabinetu ministriv Ukraïni "Polozhennja pro inkljuzivno-resursnij centr" [Resolution of the Cabinet of Ministers of Ukraine "Regulations on the Inclusive Resource Center"]. (n.d.). zakon.rada.gov.ua Retrived from https://zakon.rada.gov.ua/laws/show/545-2017$\%$ D0\%BF\#Text [in Ukrainian].

6. Nakaz Ministerstva osviti i nauki Ukraïni "Pro zatverdzhennja Polozhennja pro psihologichnu sluzhbu u sistemi osviti Ukraïni" [Order of the Ministry of Education and Science of Ukraine "On approval of the Regulations on psychological service in the education system of Ukraine"].(n.d.). zakon.rada.gov.ua Retrived from https://zakon.rada.gov.ua/laws/show/z0885-18 [in Ukrainian].

7. Nakaz Ministerstva osviti i nauki Ukraïni "Pro zatverdzhennja Primirnogo polozhennja pro komandu psihologo-pedagogichnogo suprovodu ditini $\mathrm{z}$ osoblivimi osvitnimi potrebami $\mathrm{V}$ zakladi zagal'noï seredn'oï ta doshkil'noï osviti" [Order of the Ministry of Education and Science of Ukraine "On approval of the Model Regulations on the team of psychological and pedagogical support of children with special educational needs in general secondary and preschool education"]. (n.d.). mon.gov.ua Retrived from https://mon.gov.ua/ua/npa/pro-zatverdzhennya-primirnogopolozhennya-pro-komandu-psihologo-pedagogichnogo-suprovodu-ditini-z-osoblivimi-osvitnimipotrebami-v-zakladi-zagalnoyi-serednoyi-ta-doshkilnoyi-osviti [in Ukrainian].

8. Standart vishhoï osviti za special'nistju «Psihologija» dlja pershogo (bakalavrs'kogo) rivnja vishhoï osviti [Standard of higher education in the specialty "Psychology" for the first (bachelor's) level of higher education]. osvita.ua Retrived from http://osvita.ua/vnz/standard/64445/ [in Ukrainian].

9. Chopik, O. V. (2014). Formuvannja vzaєmin ditej z vadam oporno-ruhovogo aparatu iz zdorovimi rovesnikami v umovah inkljuzivnogo navchannja [Formation of relationships of children with musculoskeletal disorders with healthy peers in terms of inclusive education]. Extended abstract of candidate's thesis Kiïv [in Ukrainian].

10. Grandin T. Teaching Tips for Children and Adults with Autism. Indiana University Bloomington. 2002. URL: https://www.iidc.indiana.edu/pages/Teaching-Tips-for-Children-andAdults-with-Autism (дата звернення: 24.01.2022). 